\title{
L6 Cells as a Tissue Culture Model for Thyroid Hormone Effects on Skeletal Muscle Metabolism
}

Ronald J. Koenig and Robert J. Smith

Howard Hughes Medical Institute, Department of Medicine; Brigham and Women's Hospital and the Joslin Diabetes Center, Boston, Massachusetts 02115

\begin{abstract}
$\mathbf{L}$ cells have been investigated as a potential tissue culture model for the study of thyroid hormone effects on skeletal muscle metabolism. Differentiated L6 myotubes contained highaffinity triiodothyronine (T3) receptors with a $K_{d}$ of $3 \times 10^{-10}$ $M$ and a maximal binding capacity of $24 \mathrm{fmol} \mathrm{T3/100} \mu \mathrm{g}$ DNA. Undifferentiated cells contained receptors with the same $K_{d}$, but the binding capacity was reduced by at least a factor of three. Sarcoplasmic reticulum vesicle calcium pumping was demonstrated in $\mathrm{L} 6$ cell homogenates. The $V_{\max }$ for calcium pumping was increased 2.5 -fold when $\mathrm{T} 3$ was present in the culture medium, but the $K_{\mathrm{d}}$ was unchanged.

L6 cells contained high affinity thyroid hormone receptors and were thyroid hormone responsive. These cells may be useful as a tissue culture model for studying the effects of thyroid hormones on skeletal muscle metabolism. In addition, the increase in T3 receptor number with the differentiated state suggests this as a model system for studying regulation of $\mathrm{T} 3$ receptor number and the role of $\mathrm{T} 3$ in the induction or maintenance of the differentiated state.
\end{abstract}

\section{Introduction}

Thyroid hormones play a central role in the regulation of the metabolism of most mammalian tissues, and skeletal muscle is no exception. For example, increased oxygen consumption is one of the hallmarks of thyrotoxicosis, and skeletal muscle is a major contributor to this phenomenon (1). Patients with hyperthyroidism frequently complain of proximal muscle weakness and may have muscle atrophy as well as morphologic and electrophysiologic abnormalities (2). Similarly, patients with hypothyroidism often complain of muscle weakness, cramps, and pains, and may have objective evidence of myopathy by biopsy and electromyography (3).

Despite these obvious clinical correlates, a fundamental understanding of the ways in which thyroid hormones influence skeletal muscle metabolism is lacking. Considerable insight has been gained through animal studies, but the conclusions

Address correspondence to Dr. Koenig, Thyroid Unit, Brigham and Women's Hospital.

Received for publication 13 November 1984 and in revised form 14 May 1985.

J. Clin. Invest.

(c) The American Society for Clinical Investigation, Inc.

0021-9738/85/08/0878/04 \$1.00

Volume 76, August 1985, 878-881 drawn are limited by the inherently complex nature of whole animal studies, and by the knowledge that hypo- and hyperthyroidism induce many metabolic changes outside skeletal muscle that could indirectly alter muscle metabolism.

A tissue culture model would obviate many of these difficulties. In this report, we describe the use of the cloned skeletal muscle cell line L6 to study the effects of thyroid hormones on muscle metabolism.

\section{Methods}

Materials. Tissue culture supplies were obtained from Gibco Laboratories, Grand Island, NY. Radioisotopes $\left({ }^{45} \mathrm{Ca},{ }^{125} \mathrm{I},{ }^{131} \mathrm{I}\right)$ were purchased from New England Nuclear, Boston, MA. L-thyroxine (T4) ${ }^{1}$ was obtained from Henning GmBH (Berlin, Federal Republic of Germany). Other iodothyronines and cytosine-1- $\beta$-arabinofuranoside were from Sigma Chemical Co. (St. Louis, MO). $\left[{ }^{125} \mathrm{I}\right]-$ and $\left[{ }^{131} \mathrm{I}\right]$ triiodothyronine (T3) were synthesized from 3,5-diiodo-L-thyronine using the chloramine T method (4).

Cell culture. The $\mathrm{L} 6$ cells used in the present studies were provided by Dr. Peter Nissley (Metabolism Branch, National Cancer Institute, Bethesda, MD), and were grown in 100-mm petri dishes as described previously (5). Cells were harvested on the 15 th or 16 th $d$ after plating, at least $6 \mathrm{~d}$ after treatment with cytosine arabinoside, at which time they consisted of fully differentiated myotubes (5). For myoblast experiments, cells were plated in a similar manner and were harvested $5 \mathrm{~d}$ later with no changes of culture medium.

Nuclear T3 receptor binding. Both differentiated myotubes and undifferentiated myoblasts were studied. Nuclei were isolated by the method of Samuels et al. (6), except that the concentration of Triton $\mathrm{X}-100$ was $0.25 \%$. By light microscopy, the nuclear preparations were contaminated with extranuclear material. This was confirmed by measurement of the protein (7) to DNA (8) ratio, which averaged 810 , rather than the 2-4 expected for pure nuclei. (The starting material ratio was 40 .) Attempts to further purify $\mathbf{L 6}$ nuclei resulted in low recoveries (10\%), which yielded insufficient material for binding studies. In addition, it was not possible to determine whether the nuclei recovered were representative of the entire population.

Binding studies were performed in duplicate by incubating sufficient nuclei from the partially purified preparation to provide $75 \mu \mathrm{g}$ of DNA with $50,000 \mathrm{cpm}\left[{ }^{125} \mathrm{I}\right] \mathrm{T} 3$ and various amounts of nonradioactive T3 $\left(3 \times 10^{-11}-6 \times 10^{-9} \mathrm{M}\right.$, or $10^{-6} \mathrm{M}$ for nonspecific binding) in a final volume of $1 \mathrm{ml}$ of STM (250 mM sucrose, $20 \mathrm{mM}$ Tris, $1 \mathrm{mM} \mathrm{MgCl}$, pH 7.85) with $2 \mathrm{mM}$ EDTA and $5 \mathrm{mM}$ dithiothreitol. Binding studies also were performed with $\left[^{125} \mathrm{I}\right] \mathrm{T} 3$ plus nonradioactive $\mathrm{T} 4$ or $3,5,3^{\prime}$ triiodothyroacetic acid (triac). Incubation was at $37^{\circ} \mathrm{C}$ for $30 \mathrm{~min}$, which was sufficient time for equilibrium to be reached. The mixtures

1. Abbreviations used in this paper: STM, $250 \mathrm{mM}$ sucrose, $20 \mathrm{mM}$ Tris, $1 \mathrm{mM} \mathrm{MgCl}$, pH 7.85; STM-T, STM with 0.25\% Triton X-100; T3, 3,5,3'-triiodo-L-thyronine; T4, thyroxine; triac, 3,5,3'-triiodothyroacetic acid. 
were then centrifuged at $1,000 \mathrm{~g}$ at $4^{\circ} \mathrm{C}$ for $8 \mathrm{~min}$. Aliquots of the supernatants from each tube were removed and counted to determine the free T3. The pellets were washed three times with iced STM-T (STM with $0.25 \%$ Triton X-100), and radioactivity was then determined. The DNA content of each tube was measured (8), and the data were subjected to Scatchard analysis.

Sedimentation profile of T3 receptors. L6 cell nuclei were prepared as described above for $\left.{ }^{125} \mathrm{I}\right] \mathrm{T} 3$ binding studies, except that only two incubation conditions were studied. Half of the nuclear preparation was incubated in a total volume of $1 \mathrm{ml}$ with $500,000 \mathrm{cpm}$ of [125 I]T3 and no nonradioactive $\mathrm{T} 3$; the other half received $10^{-6} \mathrm{M}$ nonradioactive $\mathrm{T} 3 \mathrm{in}$ addition to the tracer. After incubation for $30 \mathrm{~min}$ at $37^{\circ} \mathrm{C}$ the mixtures were centrifuged at $1,000 \mathrm{~g}$ at $4^{\circ} \mathrm{C}$ for $8 \mathrm{~min}$, and the pellets were washed three times with iced STM-T and then twice with iced STM. The nuclear receptors were extracted (9) and used for sucrose density gradient centrifugation. Nuclei also were prepared from the liver of a 350-g male Sprague-Dawley rat (9). The nuclear T3 receptors were labeled and extracted as described above, except that $\left[{ }^{131} \mathrm{I}\right] \mathrm{T} 3$ was used as tracer.

The extracted receptors were subjected to ultracentrifugation through a sucrose density gradient as described by Schwartz and Oppenheimer (10), except that centrifugation was at $198,000 g_{\max }$ for $25 \mathrm{~h}$. Approximately $1,800 \mathrm{cpm}$ of specifically bound extracted $\mathrm{L} 6$ receptors and $1,500 \mathrm{cpm}$ of liver receptors were mixed (total volume $0.3 \mathrm{ml}$ ) and placed on top of one gradient. The other gradient was overlayered with extracted receptors from liver plus the $\mathrm{L} 6$ incubation with $10^{-6}$ $M$ nonradioactive $T 3$. Both the extraction buffers and the sucrose density gradients contained $5 \times 10^{-6} \mathrm{M}$ nonradioactive $\mathrm{T} 3$ to prevent rebinding of any dissociated tracer $\mathrm{T} 3$. After centrifugation, fractions of $0.3 \mathrm{ml}$ were collected from the top with a Densi-Flow IIC sipper (Buchler Instruments, Inc., Fort Lee, NJ) and counted for $10 \mathrm{~min}$ each.

Calcium uptake studies. $3 \mathrm{~d}$ before harvesting, the cells were washed once and then maintained in serum-free media plus or minus $10^{-8} \mathrm{M}$ T3. The medium consisted of Ham's F12 with $0.1 \%$ bovine serum albumin, $100 \mathrm{U} /$ liter insulin, and $39 \mu \mathrm{g} /$ liter dexamethasone (prepared in ethanol at $39 \mathrm{mg} /$ liter). The media were changed again $1 \mathrm{~d}$ before harvesting.

On the day of harvesting, the cells were washed twice with iced $300 \mathrm{mM}$ sucrose, $40 \mathrm{mM}$ imidazole, $\mathrm{pH} 6.8$, and scraped into that buffer. The cells were centrifuged at $4^{\circ} \mathrm{C}$ at $1,000 \mathrm{~g}$ for $8 \mathrm{~min}$ and then homogenized in the same buffer. The homogenates had a final protein concentration of $3-5 \mathrm{mg} / \mathrm{ml}$ (7). Calcium uptake was then studied using the ${ }^{45} \mathrm{Ca}$ Millipore filter technique described by Kim et al. (11) for crude muscle homogenates with the following changes. Total calcium uptake was measured using the $0.2-\mu \mathrm{M} \mathrm{Ca}^{++}$buffer, and all incubations contained both sodium azide and creatine phosphate unless indicated otherwise. The potassium oxalate concentration was $10 \mathrm{mM}$ unless indicated otherwise.

\section{Results}

Nuclear T3 receptors. A typical Scatchard analysis of T3 binding to nuclear preparations of myotubes and myoblasts is shown in Fig. 1. The myotube binding curve is compatible with there being both a high affinity and a low affinity site. The latter is not typical of previously described nuclear T3 receptors $(6,9)$, and may represent a contaminating cytoplasmic protein. Subtraction analysis of these data in Fig. 1 allows one to evaluate the high affinity binding site specifically. In three separate studies, the mean $K_{\mathrm{d}}$ for $\mathrm{T} 3$ was found to be 3.4 $\times 10^{-10} \mathrm{M}$ (range 2.2-4.1 $\times 10^{-10} \mathrm{M}$ ), and the maximal binding capacity 24 fmol T3/100 $\mu \mathrm{g}$ DNA (range 23-25). The high affinity site bound triac and T4 with 1.5 and 0.09 times the affinity of $T 3$, respectively.

In contrast, the myoblasts had only the high affinity

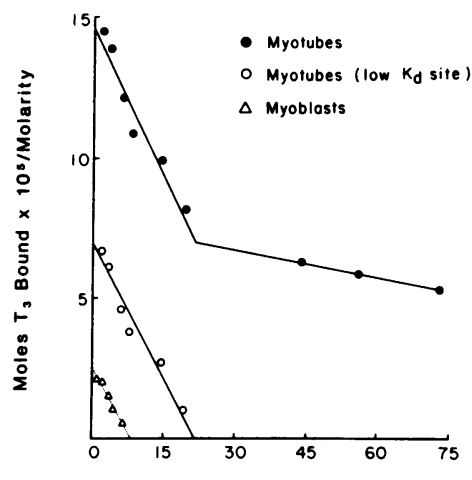

Figure 1. Scatchard analysis of T3 binding to receptors in nuclear preparations of L6 myotubes and undifferentiated myoblasts. The myotube data are replotted to show only the binding to the high affinity site, by extrapolation of the low affinity binding site portion of the curve and subtraction of this line from the high affinity portion. The high affinity sites from myotubes and myoblasts have identical slopes, indicating that the $K_{d}$ is the same for both $\left(3 \times 10^{-10} \mathrm{M}\right)$. However, the maximal binding capacity is threefold greater in the myotubes.

binding site. In two parallel studies, the binding site had a $K_{d}$ of 2.2 and $3.2 \times 10^{-10} \mathrm{M}$, with a binding capacity of 8.6 and $8.2 \mathrm{fmol} / 100 \mu \mathrm{g}$ DNA. In the third study, T3 binding was too small to accurately determine the above parameters. Thus, both the differentiated myotubes and undifferentiated myoblasts have a high affinity T3 binding site with the same $K_{d}$. However, L6 myotubes possess at least three times as many receptors as L6 myoblasts.

In order to determine whether the high affinity binding site actually represents the nuclear $\mathrm{T} 3$ receptor, $\left[{ }^{125} \mathrm{I}\right] \mathrm{T} 3$ labeled receptors were extracted from myotubes and subjected to ultracentrifugation in a sucrose density gradient along with ${ }^{\left[{ }^{131}\right.}$ I]T3 labeled receptors extracted from purified liver nuclei. As shown in Fig. 2, the receptors from L6 cells and liver have identical sedimentation profiles.

Calcium uptake. ${ }^{45}$ Calcium sequestration by $\mathrm{L} 6$ myotube homogenates was linear with time for $50 \mathrm{~min}$, and then gradually reached a plateau at $110-170 \mathrm{~min}$ (the last time

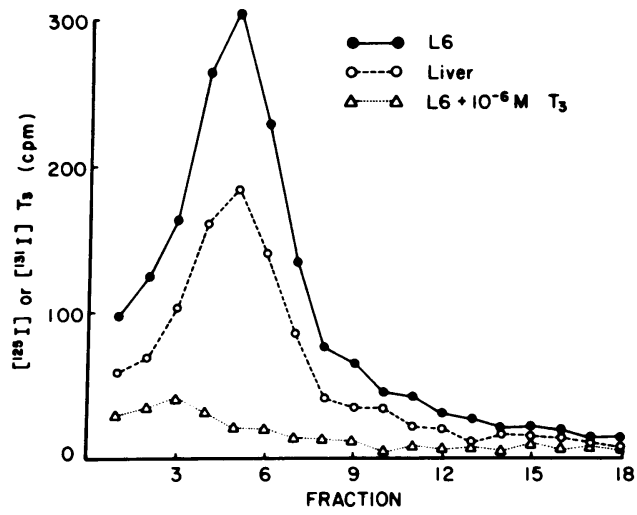

Figure 2. Sucrose density gradient centrifugation of extracted L6 and liver nuclear T3 receptors. L6 cell T3 receptors were labeled with $\left[{ }^{125} \mathrm{I}\right] \mathrm{T} 3$, and liver nuclear receptors were labeled with $\left[{ }^{131} \mathrm{I}\right] \mathrm{T} 3$. Both were extracted into $0.4 \mathrm{M} \mathrm{KCl}$, mixed, and layered onto a 5-20\% sucrose density gradient. A second gradient was overlayered with extracted L6 receptors that had been labeled with [ $\left.{ }^{125} \mathrm{I}\right] \mathrm{T} 3$ plus $10^{-6}$ $M$ nonradioactive $\mathrm{T} 3$ to assess nonspecific binding. The extraction buffers and sucrose density gradients contained $5 \times 10^{-6} \mathrm{M}$ nonradioactive $\mathrm{T} 3$ to prevent rebinding of any dissociated tracer. Gradients were centrifuged at $198,000 g_{\max }$ for $25 \mathrm{~h}$ and collected into fractions from the top. The radioactivity of each fraction was determined. 
point measured). Readdition of ATP and creatine phosphate at $110 \mathrm{~min}$ did not result in additional calcium sequestration. No ${ }^{45} \mathrm{Ca}$ was sequestered if ATP and creatine phosphate were excluded from the incubation mixture. Calcium pumping was stimulated fivefold by $10 \mathrm{mM}$ potassium oxalate.

In two studies, the mean total calcium uptake in homogenates from myotubes maintained in serum-free media without T3 was $138 \mu \mathrm{mol} \mathrm{Ca} / \mathrm{g}$ protein. Homogenates from cells incubated with T3 showed an increase in total uptake of $52 \%$ in one experiment and $38 \%$ in the second, to yield a mean uptake of $200 \mu \mathrm{mol} \mathrm{Ca} / \mathrm{g}$ protein. Kinetic analysis was done using time points from the linear portion of the uptake curves $(0,10,20$, and $50 \mathrm{~min})$. A Lineweaver-Burk plot of the data from two experiments (Fig. 3) shows that the $K_{\mathrm{m}}$ for calcium pumping was similar $(1.2 \mu \mathrm{M})$ whether the cells were maintained in the presence or absence of $\mathrm{T} 3$. In contrast, the $V_{\max }$ was increased 2.5-fold when the cells were maintained in serum-free media supplemented with T3 (12.8 vs. $5.0 \mu \mathrm{mol}$ $\mathrm{Ca} / \mathrm{g}$ protein per $\mathrm{min}$ ).

\section{Discussion}

A tissue culture model of skeletal muscle that is thyroid hormone responsive would be very useful in unraveling the ways in which these hormones affect muscle metabolism and function. We believe that L6 cells represent such a model. The L6 cell line is a continuous, cloned line of myoblasts originally derived from the thigh muscle of a newborn rat (12). These cells will divide indefinitely as myoblasts, but if allowed to grow to confluence they undergo terminal differentiation into multinucleated skeletal muscle myotubes. After differentiation, the cells have many properties of normal skeletal muscle (5) and contract spontaneously.

It is generally believed that most, if not all, of the biological activity of thyroid hormone is due to the binding of the

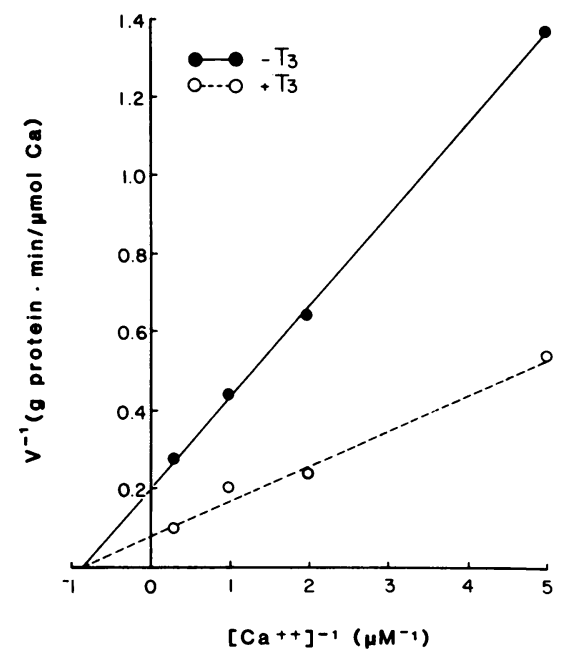

Figure 3. Calcium uptake by L6 cell crude homogenates. Data are analyzed by Lineweaver-Burk plots. Half the cells were maintained in serum free media without T3 and half with T3 for $3 \mathrm{~d}$ before harvesting. Analysis indicates the $K_{\mathrm{m}}$ is identical for both homogenates $(1.2 \mu \mathrm{M})$, but the $V_{\max }$ is 2.5 -fold greater in the T3-treated homogenates ( 12.8 vs. $5 \mu \mathrm{mol} \mathrm{Ca} / \mathrm{g}$ protein per min). Total protein per petri dish was $1.0 \mathrm{mg}$ in the absence of $\mathrm{T} 3$ and $0.9 \mathrm{mg}$ in the presence of $\mathrm{T} 3$. hormone to specific high affinity nuclear receptors, with subsequent induction of mRNA synthesis (13). Therefore, in order to determine whether L6 cells might be thyroid hormone responsive, we first sought to determine whether they possess nuclear T3 receptors. A high affinity binding component with a $K_{d}$ similar to that reported for the nuclear T3 receptor in other organs $(6,9,10,14,15)$ was identified in crude nuclear preparations of $\mathrm{L} 6$ myotubes and myoblasts. The relative binding affinity of triac and $\mathrm{T} 4$ for the myotube receptor (1.5 and 0.09 , respectively) are similar to those reported for the liver nuclear T3 receptor (1.6 and 0.1) (16). In addition, the putative T3 receptor from L6 cells and the liver nuclear T3 receptor have identical sedimentation profiles. The myotube preparations contained an additional low affinity, high capacity T3 binding site that may be a cytoplasmic protein.

We are unaware of any published studies of nuclear T3 receptors in skeletal muscle. In two reports of nuclear T3 receptors in uterus $(14,15)$, the $K_{d}$ was found to be between $10^{-9}$ and $10^{-10} \mathrm{M}$, and the maximal binding capacity to be 11 and $24.9 \mathrm{fmol} \mathrm{T} 3 / 100 \mu \mathrm{g}$ DNA. These results are similar to our L6 myotube data, which give a $K_{d}$ of $3 \times 10^{-10} \mathrm{M}$ and a binding capacity of $24 \mathrm{fmol} / 100 \mu \mathrm{g}$ DNA.

Scatchard analysis of the T3 receptor binding in L6 myotubes and myoblasts showed that the differentiated state is associated with an increased number of receptors. It is not known whether these receptors are essential for differentiation to occur or are a consequence of that process. Obviously, it would be of great importance to answer this question, and to identify the factors that regulate $\mathrm{T} 3$ receptor number.

Having shown that L6 myotubes contain T3 receptors, it was important to demonstrate the functionality of those receptors. We chose to investigate calcium pumping by the sarcoplasmic reticulum because it has been shown to be T3 dependent in animal muscle. It also has been demonstrated that this process can be studied in crude homogenates of skeletal muscle (11). This is an important observation because the recovery, when isolating sarcoplasmic reticulum, is quite low $(5-10 \%)$ (11), making it very difficult to assess changes in the number of pump units $\left(V_{\max }\right)$ or to know that the material recovered is representative. Using the crude homogenate technique, we found that calcium pumping in L6 homogenates has the properties that characterize sarcoplasmic reticulum pumping in rat skeletal muscle homogenates: it is energy and oxalate dependent, is not inhibited by azide, and occurs at micromolar concentrations of ionized calcium.

L6 cell homogenate calcium pumping differs in several ways from that observed in rat skeletal muscle, however. The $V_{\max }$ measured in the former in the presence of T3 was 12.8 $\mu \mathrm{mol} \mathrm{Ca} / \mathrm{g}$ protein per min, whereas the activity in various skeletal muscle homogenates ranged from 8 to $56 \mu \mathrm{mol} \mathrm{Ca} / \mathrm{g}$ wet weight per min (11). The percentage of wet weight that is protein in these muscles was not stated, but obviously the $V_{\max }$ for L6 cells is considerably lower than that for rat skeletal muscle. This is consistent with the time it takes for each tissue to reach isotopic equilibrium in calcium pumping: $2 \mathrm{~h}$ for L6 cells, compared with 10-20 min for skeletal muscle homogenates. However, it should be noted that the $K_{\mathrm{m}}$ for calcium pumping was similar in both systems: $1.2 \mu \mathrm{M}$ for L6 and 1.2$2.8 \mu \mathrm{M}$ for skeletal muscles (11).

L6 cell homogenates showed a 2.5 -fold increase in the $V_{\max }$ for calcium pumping when the cells had been maintained in T3-containing media, suggesting that the number of pump 
units is T3 dependent. Similar findings have been reported for rat soleus muscle $(17,18)$ and for total hindlimb muscle $(19)$.

These data show that L6 cells contain T3 receptors and are $\mathrm{T} 3$ responsive in culture. It is hoped that $\mathrm{L} 6$ cells will provide a useful tissue culture model for studying the influences of thyroid hormones on skeletal muscle metabolism.

\section{Acknowledgments}

This work was supported in part by National Institute of Arthritis, Diabetes, Digestive and Kidney Disease grant AM-18616.

\section{References}

1. Barker, S. B., and H. M. Klitgaard. 1952. Metabolism of tissues excised from thyroxine-injected rats. Am. J. Physiol. 170:81-86.

2. Gruener, R., L. Z. Stern, C. Payne, and L. Hannapel. 1975. Hyperthyroid myopathy. Intracellular electrophysiological measurements in biopsied human intercostal muscle. Neurol. Sci. 24:339-349.

3. Khaleeli, A. A., D. G. Griffith, and R. H. T. Edwards. 1983. The clinical presentation of hypothyroid myopathy and its relationship to abnormalities in structure and function of skeletal muscle. Clin. Endocrinol. 19:365-376.

4. Weeke, J., and H. Orskov. 1973. Synthesis of ${ }^{125}$ I monolabelled $3,5,3^{\prime}$-triiodothyronine and thyroxine of maximum specific activity for radioimmunoassay. Scand. J. Clin. Lab. Invest. 32:357-360.

5. Smith, R. J., S. Larson, S. E. Stred, and R. P. Durschlag. 1984. Regulation of glutamine synthetase and glutaminase activities in cultured skeletal muscle cells. J. Cell Physiol. 120:197-203.

6. Samuels, H. H., J. S. Tsai, J. Casanova, and F. Stanley. 1974. Thyroid hormone action. In vitro characterization of solubilized nuclear receptors from rat liver and cultured $\mathrm{GH}_{1}$ cells. J. Clin. Invest. 54: 853-865.

7. Bradford, M. M. 1976. A rapid and sensitive method for the quantitation of microgram quantities of protein utilizing the principle of protein-dye binding. Anal. Biochem. 72:248-254.

8. Giles, K. W., and A. Myers. 1965. An improved diphenylamine method for the estimation of deoxyribonucleic acid. Nature (Lond.) 206:93.

9. Silva, J. E., H. Astier, U. Thakare, H. L. Schwartz, and J. H. Oppenheimer. 1977. Partial purification of the triiodothyronine receptor from rat liver nuclei. J. Biol. Chem. 252:6799-6805.

10. Schwartz, H. L., and J. H. Oppenheimer. 1978. Nuclear triiodothyronine receptor sites in brain: probable identity with hepatic receptors and regional distribution. Endocrinology. 1Q3:267-273.

11. Kim, D. H., F. A. Witzmann, and R. H. Fitts. 1981. A comparison of sarcoplasmic reticulum function in fast and slow skeletal muscle using crude homogenate and isolated vesicles. Life Sci. 28: 2223-2229.

12. Yaffe, D. 1968. Retention of differentiation potentialities during prolonged cultivation of myogenic cells. Proc. Natl. Acad. Sci. USA. 61:477-483.

13. Baxter, J. D., N. L. Eberhardt, J. W. Apriletti, L. K. Johnson, R. D. Ivarie, B. S. Schachter, J. A. Morris, P. H. Seeburg, H. M. Goodman, K. R. Latham, J. R. Polansky, and J. A. Martial. 1979. Thyroid hormone receptors and responses. Recent Prog. Horm. Res. 35:97-153.

14. Mukku, V. R., J. L. Kirkland, M. Hardy, and G. M. Stancel. 1983. Evidence for thyroid hormone receptors in uterine nuclei. Metab. Clin. Exp. 32:142-145.

15. Evans, R. W., A. P. Farwell, and L. E. Braverman. 1983. Nuclear thyroid hormone receptor in the rat uterus. Endocrinology. 113:1459-1463.

16. Koerner, D., H. L. Schwartz, M. I. Surks, and J. H. Oppenheimer. 1975. Binding of selected iodothyronine analogues to receptor sites of isolated rat hepatic nuclei. J. Biol. Chem. 250:6417-6423.

17. Fitts, R. H., W. W. Winder, M. H. Brooke, K. K. Kaiser, and J. O. Holloszy. 1980. Contractile, biochemical, and histochẹmical properties of thyrotoxic rat soleus muscle. Am. J. Physiol. 238:C15C20.

18. Kim, D. H., F. A. Witzmann, and R. H. Fitts. 1982. Effect of thyrotoxicosis on sarcoplasmic reticulum in rat skeletal muscle. Am. J. Physiol. 243:C151-C155.

19. Fanburg, B. L. 1968. Calcium transport by skeletal muscle sarcoplasmic reticulum in the hypothyroid rat. J. Clin. Invest. 47: 2499-2506. 